\title{
HATÁRON ÁTÍVELŐ AKVIZÍCIÓS ÉS FÚZIÓS TRANZAKCIÓK SIKERESSÉGÉT MEGHATÁROZÓ TÉNYEZŐK VIZSGÁLATA
}

A tốkeerốs magyar vállalatok az utóbbi idóben, hasonlóan a külföldi multinacionális vállalatokhoz, egyre gyakrabban vesznek részt határon átívelő akvizíciós vagy fúziós tranzakcióban. Az akvizíciók és fúziók sláger jellegét ugyanakkor beárnyékolják a tanácsadók és a gazdasági sajtó által hivatkozott kutatások és felmérések eredményei, melyek szerint a megvalósított tranzakciók körülbelül 80\%-a kudarccal végzốdik és pusztán csak $\mathbf{2 0 \%}$-a sikeres. Jelen kutatás a határon átívelő akvizíciós vagy fúziós tranzakciók sikerességére alkalmas vizsgálati rendszer felvázolásával, valamint elő́rejelzési célokra is alkalmas, többváltozós matematikai-statisztikai eljárásokból összeállított modellrendszer révén igyekszik segítséget nyújtani az ilyen jellegú tranzakciókat tervezó vállalatoknak.

A magyar gazdaság az 1989/90-es gazdasági átalakulást követôen az „emerging markets” kategóriából folyamatosan az egyre fejlettebb gazdaságok csoportjába kerül. Biztató jelei ennek az OECD, valamint az európai uniós tagságon túlmenóen az elmúlt 4-5 évben magyar cégek által végrehajtott határon átívelô akvizíciós és (vagy) fúziós tranzakciók (Cross-Border Mergers \& Acquisitions). Természetes dolog, hogy a gazdaság zászlóshajói a MOL, az OTP, valamint a DANUBIUS, TVK stb. érintettek az említett témában, hiszen a M\&A tranzakciók - fóleg, ha azok a határon átirányulnak, bizonyos méret -, tókenagyság és menedzsmentismeretek meglétét kívánják meg. Annak ellenére, hogy a megfeleló magyar cégek életében ezek mondhatni új dolgok, világviszonylatban az M\&A tranzakciókban aktív időszakok az elmúlt százegynéhány évben többször is előfordultak. Az akvizíciók és fúziók sláger jellegét ugyanakkor beárnyékolják a tanácsadók és a gazdasági sajtó által hivatkozott kutatások és felmérések eredményei, melyek szerint a megvalósított M\&A tranzakciók körülbelül $80 \%$-a kudarccal végződik és pusztán csak $20 \%$-a sikeres.

Ezen információk alapján King szerint két következtetés vonható le (King, 2002). Először, a M\&A tranzakciók általában nem növelik a vállalatok értékét. Amennyiben ez igaz, akkor miért ragaszkodnak mégis a vállalatvezetốk az ilyen jellegú tranzakciók folytatásához, miért nem képesek megakadályozni a vállalatirányítási rendszerek ezeket a folyamatokat? Másodszor, az M\&A tranzakciók növelik ugyan a vállalatok értékét, de a kutatók nem tudják kimutatni ezen értéknövekményt, a véletlen vagy mérsékelt kapcsolatokból, a felhasznált mintákból vagy mérési problémákból kifolyólag (King, 2002).

Kutatásom során a második problémával foglalkoztam. Ebból kifolyólag igyekeztem a meglévő, releváns szakirodalom feldolgozása alapján egy empirikus kutatás keretein belül fényt deríteni azokra a tranzakciókra, illetve a részt vevő vállalatokat jellemző változókra és azok kritikus értékeire, amelyek révén bizonyos hibahatárok között becslést lehet adni a tervezett tranzakció eredményességére. Ezt követôen a kapott eredményekre támaszkodva kialakítani egy modellt, amelyet az eddigi megvalósított tranzakciók mintáján tesztelve (módosítva az eredmények ismeretében) alkalmassá lehet tenni egy magyarországi cég számára sikeres, határon átívelő M\&A tranzakció lebonyolításának megtervezésére és megvalósítására. Célom az M\&A tranzakciók vizsgálatához kapcsolódó, két egymástól eltérô szakirodalmi irányzat, a hagyományos megközelitési mód és a szervezeti megközelítési mód integrálása volt egy modellen belül. Az M\&A tranzakciókat vizsgáló

\section{VEZETÉSTUDOMÁNY}


eddigi modellek mindig csak egy megközelítési módra épültek. A kialakított modellben ezért egymást kiegészítve szerepeltettem olyan változókat és eljárásokat, amelyekre az egyes megközelítési módok épülnek. A két irányzat integrációjától elvárt eredmény az egyes megközelítési módok erősségeinek ötvöződése, illetve a gyengeségeik kiküszöbölése volt.

\section{A felhasznált módszerek}

A kutatás alapvetően magyarázó jellegú, a cél magyarázatok keresése. Mezoszintû statisztikai elemzésról lévén szó, így a vizsgálat a gazdasági szereplók egy meghatározott csoportjára vonatkozik. A keresztmetszeti vizsgálat a 2000-es idôpontra vonatkozik. Az elemzésben a vizsgálat tárgyát képezó alapsokaság az akvizíciók és fúziók halmazának (M\&A) határon átívelő akvizíciók és fúziók (CBM\&A) részhalmaza. A minta elemei ezen szegmensen belül is a 2000. évben végrehajtott 1 egymilliárd USD-értéket meghaladó 175 darab megatranzakció. Az adatgyứjtés mintavételes, a mintavételi eljárás a nem véletlen mintavételek közül a koncentrált minta módszer. Az adatok vizsgálatánál másodelemzésre került sor.

Megfogadva Hitt és társai ajánlását a stratégiai menedzsment jelenségek jövóbeli vizsgálatára vonatkozóan, mely szerint ezen jelenségek összetettek, ezért egy elmélettel nem magyarázhatók, így több elmélet integrációjára van szükség a problémák megoldásának keresésére (Hitt et al., 1998), kutatásomban a CBM\&A tranzakciók sikerességének vizsgálatánál a hagyományos és szervezeti megközelítési módokat integráltam egy modellbe.

Kutatásomban a CBM\&A tranzakciók sikerességének vizsgálatánál a piaci hozamokon alapuló elemzési módszert alkalmaztam. Ez a módszer a vállalat részvényesei által realizálható hozamok vizsgálatára épül. A módszeren belül kétféle eljárással határoztam meg a hozamot: a CAR-, illetve a BAHR-eljárásokkal. Mindkét alkalmazás esetében csökkentettem a kapott hozamokat egy referencia-benchmark hozammal (tóke alternatíva költsége), amit a befektetók egy hasonló kockázatú befektetéstól elvárhattak. A referenciahozamot a tranzakcióban szereplő vállalatok méretéhez és iparágához igazodva választottam.

Hosszú távú elemzésrôl lévén szó a választott eseményablak a $(-3 ;+3)$ év. Ez azt jelenti, hogy a tranzakciót megelőzó három év adatait, valamint a tranzakciót követő három év adatait szerepeltettem az elemzésben. Kutatásomban a sikert a felvásárló vállalat szempontjából értelmeztem, és a következóképpen határoztam meg: egy tranzakciót akkor tekintettem teljes siker- nek a felvásárló vállalat szemszögéből, ha a felvásárló vállalat részvényeinek tranzakció elôtti CAR-, illetve BAHR-hozama negatív volt, a tranzakciót követôen pedig pozitívvá vált. A tranzakció kudarcáról beszélhetünk, ha fordított a helyzet. Részleges a siker, ha a felvásárló vállalat részvényeinek tranzakció utáni és elốtti CAR-, illetve BAHR-hozamainak értékei között javulás észlelhetố, de elójelváltás nem történt (a negatív érték csökkent, a pozitív nôtt). Részleges a kudarc, ha a felvásárló vállalat részvényeinek tranzakció utáni és elótti CAR, illetve BAHR hozamainak értékei között romlás észlelhetô, de elôjelváltás nem történt )a negatív érték nőtt, a pozitív csökkent).

A mintában szereplő egyes mega CBM\&A tranzakciók esetében több változóra vonatkozóan is végeztem megfigyeléseket. Mivel kutatásomban a vizsgálni kívánt változók száma meghaladta az ötvenet, így a faktoranalízis számomra olyan lehetôséget jelentett, amely során az eredeti változók számánál lényegesen kevesebb számú hipotetikus, mesterséges változót (faktort) tudtam képezni úgy, hogy a faktorok jól reprezentálták az eredeti változókat és tartalmazták a változórendszerben rejlő információmennyiség jelentôs részét. (1. ábra)

Az elemzés következő fázisában azt is vizsgáltam, hogy a mega CBM\&A tranzakciók általam végzett csoportosítása a felvásárló vállalatok szempontjából sikeres és sikertelen tranzakciókra a CAR-, illetve BAHRhozamok alapján igazolható-e más típusú eljárással és egyéb változók felhasználásával. Az alkalmazott módszer a klaszterelemzés, ezen belül is a k-középpontú módszer. A klaszteranalízist követôen a faktorok, vagy a faktorokkal szoros kapcsolatban álló változók közül diszkriminanciaanalízissel kiválasztottam azokat a tényezóket, amelyek a leginkább elkülönítették a kialakult csoportokat.

A továbbiakban a tervezett modell megvalósításánál regressziós analízis segítségével egy többváltozós lineáris regressziós modellt hoztam létre. Mivel modellemben a már korábban ismertetett hagyományos és szervezeti megközelítési módokat integráltam, ezért a változók körének kiválasztásánál kiindulásként e kettôs csoportosítást követtem. A szervezeti megközelítési mód esetén olyan tényező́k szerepeltek nagy hangsúlylyal, amelyek pénzben nem mérhetőek és esetenként számszerúsítésük is gondot okoz, mint például a kultúra kérdése. A hagyományos megközelítési mód esetében a hangsúlyt a pénzügyi folyamatokra és az ezeket befolyásoló tényezókre helyeztem, így az alkalmazni kívánt változók a mérlegból, eredménykimutatásból és a pénzáramlás- jelentésból származó pénzügyi mutatószámokat ölelték fel. 
A vizsgált tényezók és az azokat képviselő változók

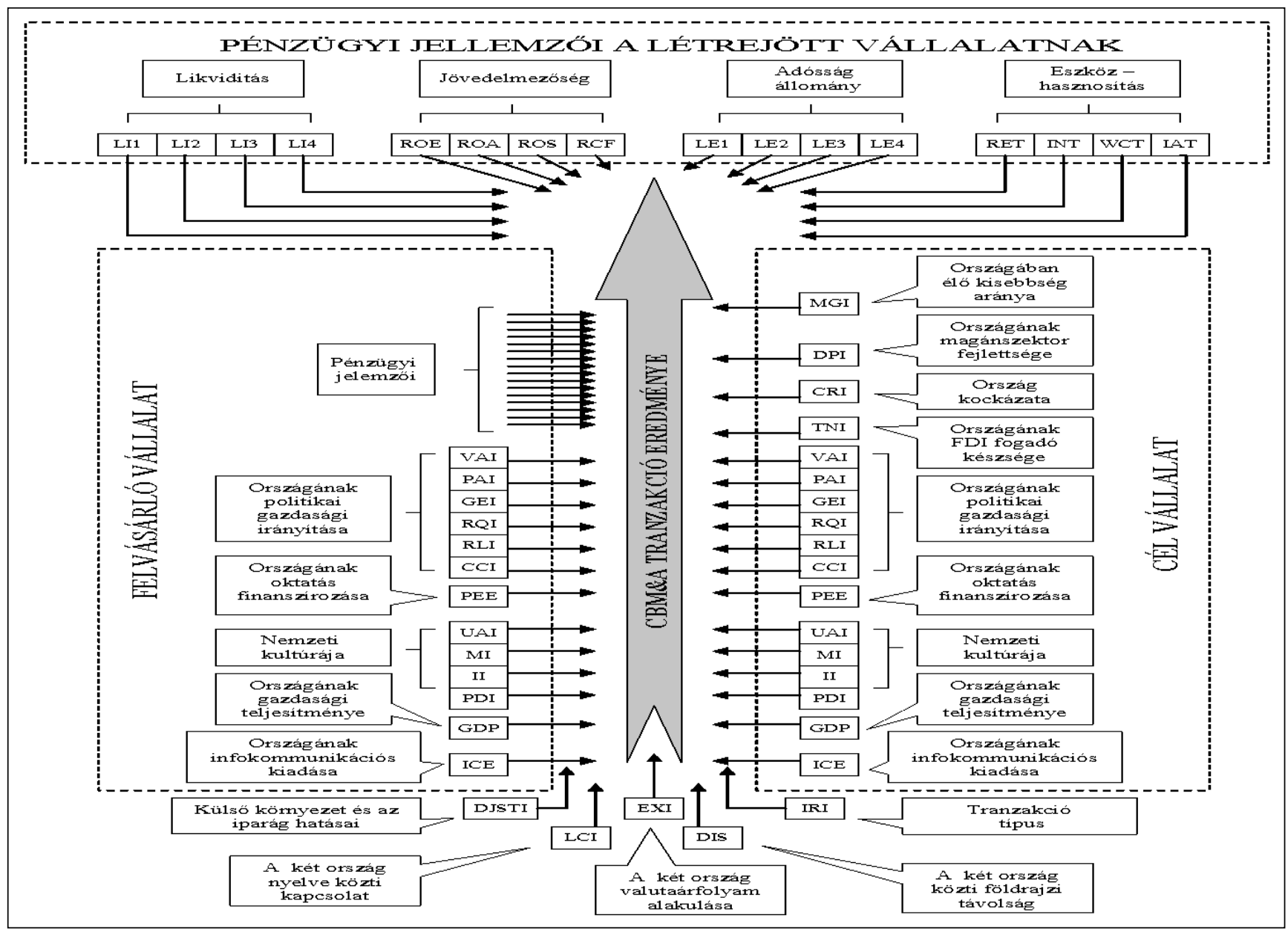

Forrás: saját készítés

A modellkészítés során kiindulási alapként többváltozós lineáris regressziós modellt alkalmaztam. Ennek oka a következô. A vizsgált témában készült elôzô kutatások (Black et al., 2001,; Conn et al., 2001) szintén ezt a modelltípust alkalmazták. Így a kutatás eredményeinek az elôzô kutatások eredményeivel való összevethetôségének ez volt az alapfeltétele. (2. ábra)

A modell a következókben lépte túl az elôző modellek korlátait. A szakirodalomban fellelhető M\&A tranzakciók vizsgálatához kapcsolódó, két egymástól eltérô irányzat: a hagyományos megközelítési mód és a szervezeti megközelítési mód integrálására került sor egy modellen belül. Az eddigi két referenciamodell csak a hagyományos megközelítési módra épült. A vizsgált magyarázóváltozók száma nagyságrenddel meghaladta az említett modellek magyarázó változóinak számát.

\section{A kialakított modell struktúrája}

2. ábra

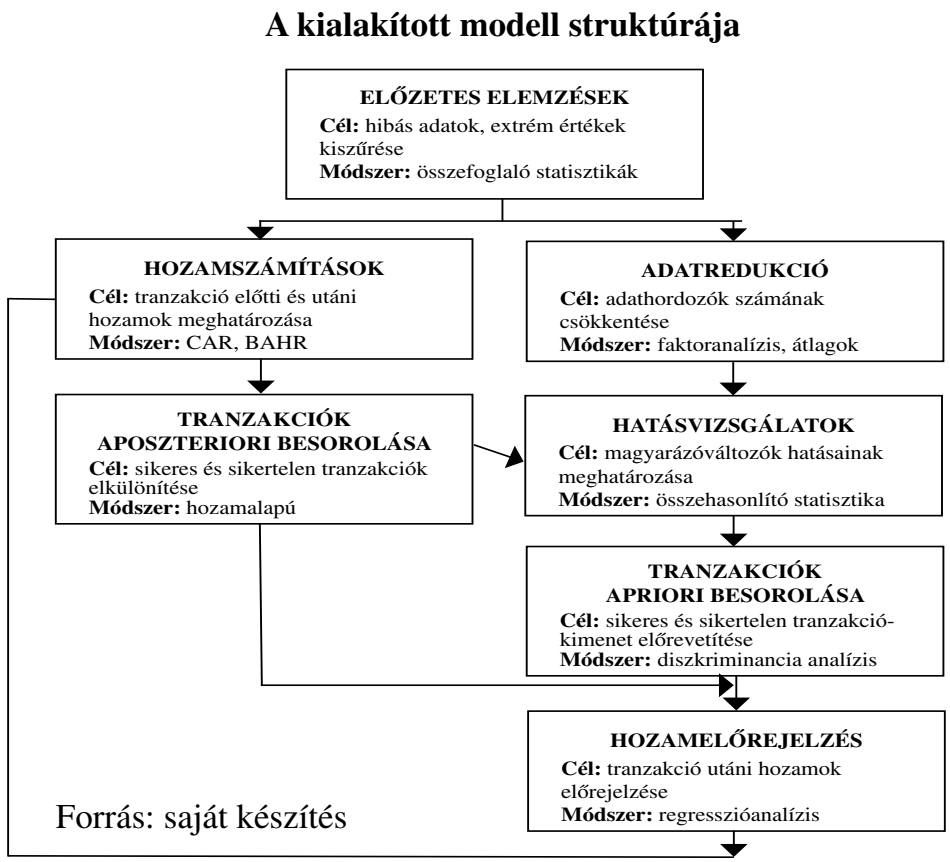




\section{A kutatás eredményei}

A CAR- és BAHR-eljárással végzett hozamszámítás jelentôs eltérést eredményezett. Ennek oka az eljárások érzékenységbeli különbségében keresendô. A CAReljárás feltételezi, hogy az adott részvényt mindennap nyitáskor megvásároljuk, és nap végén értékesítjük, ami elméleti síkon elképzelhetô, de gyakorlati megvalósítása valószínútlen. Fóleg hosszú távon, mivel a gyakori vásárlásokkal és értékesítésekkel járó tranzakciós költségek mértéke felemésztené az árfolyamnyereséget. A gyakorlathoz sokkal közelebb álló BAHReljárás ezzel szemben csak a vizsgált időszak kezdeti és végi árfolyamokkal számol, ami a kalkuláció szempontjából is jóval egyszerúbb. Célszerú tehát hosszú távú elemzésekhez a BAHR-módszert alkalmazni. A BAHR-eljárással számított mintában szereplő felvásárló vállalatok $C B M \& A$ tranzakciót követố hosszú távú hozama összhangban van Conn és társai (Conn et al., 2001) kutatásának eredményével, de eltér Black és társai (Black et al., 2001) kutatásainak eredményeitól. Ennek oka valószínúleg a választott időszakok eltérésében keresendô. Jelen kutatás a 2000-es évben végrehajtott tranzakciókat vizsgálta, amely idôszak részét képezi a konzisztens eredményeket mutató Conn és társai (Conn et al., 2001) által vizsgált 1984-2000-ig terjedő időszaknak. Ezzel szemben az eltérő eredményeket reprezentáló Black és társai (Black et al., 2001) kutatása az 1985-1995-ig terjedő időszakban létrejött tranzakciókat vizsgálta. (1 táblázat)

\section{A kutatás eredményeinek összehasonlítása az eddigi CBM\&A tranzakciót követô hosszú távú jövedelmezôséget vizsgáló tanulmányok eredményeivel}

\begin{tabular}{|l|c|l|l|}
\hline \multicolumn{1}{|c|}{ Szerző } & $\begin{array}{c}\text { Minta- } \\
\text { méret } \\
\text { és időszak }\end{array}$ & \multicolumn{1}{|c|}{ Módszer } & $\begin{array}{c}\text { Hosszú távú } \\
\text { BAHR- vagy } \\
\text { CAR-hozam }\end{array}$ \\
\hline $\begin{array}{l}\text { Black et al. } \\
(2001)\end{array}$ & $\begin{array}{c}261 \text { ügylet } \\
1985-95\end{array}$ & $\begin{array}{l}\text { 3-5 éves BAHR módosítva } \\
\text { méret, MTBV és elózó } \\
\text { teljesítmény alapján }\end{array}$ & $\begin{array}{l}-13 \% 1 \text { évre } \\
-43 \% 5 \text { évre }\end{array}$ \\
\hline $\begin{array}{l}\text { Conn et al. } \\
(2001)\end{array}$ & 1065 ügylet & $\begin{array}{l}1-2-3 \text { éves BAHR módosítva } \\
\text { méret és előzó teljesítmény } \\
\text { alapján }\end{array}$ & $\begin{array}{l}6 \% 1 \text { évre } \\
0 \% 3 \text { évre }\end{array}$ \\
\hline $\begin{array}{l}\text { Balogh } \\
(2005)\end{array}$ & $\begin{array}{l}175 \text { ügylet } \\
2000\end{array}$ & $\begin{array}{l}\text { 3 éves BAHR és CAR } \\
\text { módosítva méret és előzó } \\
\text { teljesítmény alapjén }\end{array}$ & $\begin{array}{l}\text { BAHR 0\% 3 évre } \\
\text { CAR 19,4\% 3 évre }\end{array}$ \\
\hline
\end{tabular}

Forrás: Conn et al., 2002, 46. old. és saját készítés (a szürke hátterú sor mutatja a saját vizsgálatot)
A mintámban szereplő CBM\&A tranzakciók besorolásának általam számított eredményei alapján megállapítható, hogy szigorúan vett sikerról csak a tranzakciók $16 \%$-nak esetén beszélhetünk. Ez az eredmény igen közel esik a bevezetőben említett 20\% siker -80\% kudarc általános arányhoz. Kevésbé szigorúan értelmezve a siker kritériumait az általam számított eredményarány a valamivel kedvezóbb 37\% siker és 63\% kudarc szinten állt be, amely még mindig csak egy gyenge közelítése a Kleinert és Klodt, 2002 által egy tranzakció sikerességére vonatkozóan megfogalmazott pénzérmefeldobás valószínúségi arányának (Kleinert-Klodt 2002). (3. ábra)

\section{3. ábra}

A mintában szerepró CBM\&A tranzakciók végeredmény szerinti besorolása

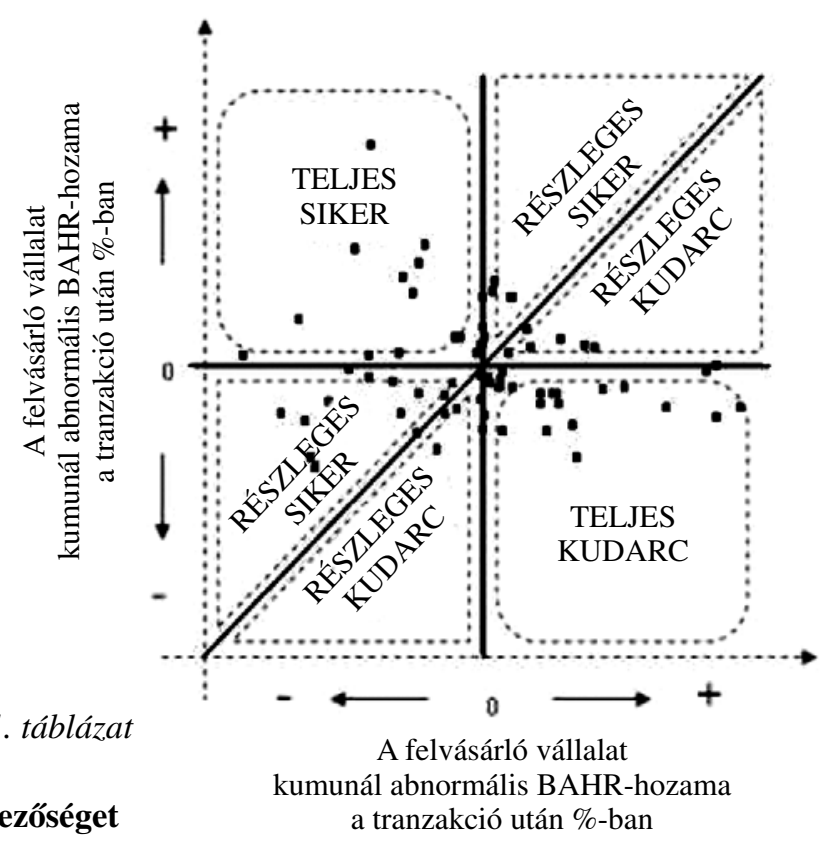

Forrás: saját készítés az SPSS eredményei alapján

Az adatredukció során a nagyszámú kezdeti kiindulási változóból, (több változó már eleve adattömörítés révén lett létrehozva [pl. pénzügyi mutatószámok - indexszámítás, transznacionalitási index - faktoranalízis]), adatredukciós módszerekkel sikerült csökkentenem az adatok számát olyan módon, hogy a mögöttes információtartalom a lehetô legkisebb mértékben szenvedjen csorbát. Ezt egyszerú matematikai-statisztikai, valamint többváltozós adatelemzési módszerekkel oldottam meg. A hagyományos megközelítési mód által vizsgált változókból így 
31 származtatott változót, míg a szervezeti megközelítési mód által vizsgált változókból 11 származtatott változót hoztam létre. A hatásvizsgálatok során az adatredukció révén kapott származtatott magyarázóváltozók eredményváltozóra gyakorolt hatását igyekeztem kimutatni. A kiindulási állapothoz képest így eredményképpen a szervezeti megközelítési mód származtatott magyarázóváltozóiból 7, míg a hagyományos megközelítési mód származtatott magyarázóváltozóiból 18 maradt. Ezek a mesterséges súrített változók, amelyek eredményváltozóra gyakorolt hatása a legjelentôsebb, képezték a késóbbi elemzések bemeneti adatait.

A tranzakciók a priori (elózetes) besorolásánál abból a feltevésból indultam ki, hogy lehetséges a hatásvizsgálat során már korábban kiválasztott származtatott magyarázóváltozók segítségével előre jelezni egy tranzakció kimenetét. Az egyes tranzakciókat a teljes siker, részleges siker, részleges kudarc, teljes kudarc csoportok valamelyikébe igyekeztem besoroltatni a diszkrimináló függvények segítségével. A vizsgálatot elvégeztem külön-külön a szervezeti és a hagyományos megközelítési mód származtatott változóira, majd egy közös kombinált származtatott magyarázóváltozó-halmazra. A kombinált modell 96,9\%-os besorolási pontossággal megelőzte a 42,2\%-os besorolási pontosságú szervezeti modellt és a 90,9\%-os besorolási pontosságú hagyományos modellt is. (2. táblázat)

\section{2. táblázat}

A modellek összehasonlítása besorolási pontosságuk alapján

\begin{tabular}{|c|c|c|c|}
\hline \multirow{2}{*}{$\begin{array}{c}\text { Besorolási } \\
\text { pontosság } \\
\text { \%-ban }\end{array}$} & \multicolumn{3}{|c|}{ Modelltípus } \\
\cline { 2 - 4 } & Szervezeti & Hagyományos & Kombinált \\
\cline { 2 - 4 } & 42,2 & 90,9 & 96,9 \\
\hline
\end{tabular}

Forrás: saját készítés az SPSS eredményei alapján

A CBM\&A tranzakció utáni hozam elôrejelzésre lineáris regressziómodelleket alkalmaztam. Itt szintén három modellt készítettem. A 8 modellszelekciós kritérium alapján 5 esetben a kombinált modell bizonyult a legjobbnak. Ez a modell a 25 származtatott magyarázó változóval 0,551 nagyságú magyarázóerót testesített meg a mintában szereplő CBM\&A tranzakciók tranzakció utáni BAHR-hozam-alakulására vonatkozóan. A modell finomítása során hét lépésben sikerült eljutnom a végsố változathoz, amely már csak 18 származtatott magyarázóváltozóval, de már 0,774 magyarázó erốt képviselt a mintában szereplő CBM\&A-tranzakciók tranzakció utáni BAHR-hozam alakulására vonatkozóan. A 18 származtatott magyarázóváltozó közül 6 a szervezeti megközelítési mód, 12 a hagyományos megközelítési mód kategóriából került ki. (3. és 4. táblázat)

3. táblázat

A regressziós modellek összehasonlítása a modellszelekciós kritériumok alapján

\begin{tabular}{|c|l|c|c|c|}
\hline \multirow{2}{*}{$\begin{array}{c}\text { S. } \\
\text { sz. }\end{array}$} & \multirow{2}{*}{ Kritérium } & \multicolumn{3}{|c|}{ Modelltípus } \\
\cline { 3 - 5 } & & Szervezeti & $\begin{array}{c}\text { Hagyomá- } \\
\text { nyos }\end{array}$ & Kombinált \\
\hline 1. & SGMASQ & 963,71 & 653,15 & 610,12 \\
\hline 2. & AIC & 1191,68 & 870,03 & 580,96 \\
\hline 3. & FPE & 1204,65 & 1040,97 & 1105,85 \\
\hline 4. & GCV & 1284,96 & 1607,77 & 3254 \\
\hline 5. & HQ & 1345,58 & 1160,96 & 862,16 \\
\hline 6. & SCHWARZ & 1719,09 & 2077,27 & 1911,41 \\
\hline 7. & SHIBATA & 1084,18 & 580,44 & 300,29 \\
\hline 8. & R 2 & 0,29 & 0,52 & 0,55 \\
\hline
\end{tabular}

Forrás: saját készítés a GRETL eredményei alapján

\section{4. táblázat}

A javított és a kiindulási regressziós modellek összehasonlítása a modellszelekciós kritériumok alapján

\begin{tabular}{|c|c|c|c|c|}
\hline \multirow{2}{*}{$\begin{array}{l}\text { S. } \\
\text { SZ. }\end{array}$} & \multirow[b]{2}{*}{ Kritérium } & \multicolumn{3}{|c|}{ Modell típus } \\
\hline & & $\begin{array}{c}\text { Kiindulási } \\
\text { modell }\end{array}$ & $\begin{array}{c}1 \text { javított } \\
\text { modell }\end{array}$ & $\begin{array}{l}\text { Végsó } \\
\text { modell }\end{array}$ \\
\hline 1. & SGMASQ & 610,12 & 523,08 & 306,98 \\
\hline 2. & AIC & 580,96 & 545,89 & 408,91 \\
\hline 3. & FPE & 1105,85 & 931,74 & 489,25 \\
\hline 4. & $\mathrm{GCV}$ & 3254 & 2391,24 & 755,65 \\
\hline 5. & HQ & 862,16 & 797,90 & 545,65 \\
\hline 6. & SCHWARZ & 1911,41 & 1715,61 & 976,31 \\
\hline 7. & SHIBATA & 300,29 & 293,21 & 272,80 \\
\hline 8. & $\mathbf{R}^{2}$ & $\mathbf{0 , 5 5}$ & 0,61 & 0,774 \\
\hline 9. & Változók sz. & 25 & 24 & 18 \\
\hline
\end{tabular}

Forrás: saját készítés a GRETL eredményei alapján

A szervezeti megközelítési mód származtatott változói: - a felvásárló és a célvállalat országai közötti földrajzi távolság; - az információs és telekommunikációs kiadások különbsége a felvásárló és a cél vállalat országai között; - a központi politikai és gazdasági irányítás közti minőségi különbség a felvásárló és a célvállalat országai között; - a felvásárló és a célvállalat országai közti kulturális különbség; - a felvásárló és a cél

\section{VEZETÉSTUDOMÁNY}


vállalat országainak nyelvei közti hasonlóság; - a cél vállalat országában élô, a felvásárló vállalat országbéli kisebbség aránya.

A hagyományos megközelítési mód származtatott változói: - iparági kapcsolat a felvásárló és a célvállalat között; - a cél- és a felvásárló vállalat országkockázatai közötti különbség; - a létrejött közös vállalat tranzakció utáni átlagos készletek forgási sebességi mutató értéke; - a létrejött közös vállalat tranzakció utáni átlagos eszközök forgási sebességi mutató értéke; - a létrejött közös vállalat tranzakció utáni átlagos vevớk forgási sebességi mutató értéke; - a létrejött közös vállalat tranzakció utáni átlagos idegentôke-aránya; - a létrejött közös vállalat tranzakció utáni átlagos rövid távú eladósodottsága; - a létrejött közös vállalat tranzakció utáni átlagos hosszú távú eladósodottsága; - létrejött közös vállalat tranzakció utáni átlagos likviditási gyorsrátája; - létrejött közös vállalat tranzakció utáni átlagos likviditási rátája; - a létrejött közös vállalat tranzakció utáni átlagos vevốk aránya a forgóeszközökön belül mutató értéke; - a létrejött közös vállalat tranzakció utáni átlagos készletek aránya a forgóeszközökön belül mutató értéke.

Található a végsố modellben 3 olyan magyarázóváltozó is, amelyek „,p” értéke nagyobb volt, mint 0,1 . Ez azt jelenti, hogy ezek a változók $10 \%$ szignifikanciaszinten nem szignifikánsak. Általánosan elfogadott gyakorlat azonban nem szignifikáns, de elméletileg a modellbe illố magyarázóváltozó megtartása, ha a „„" statisztikája abszolút értékben legalább 1, vagy a „p" értéke kisebb, mint 0,25 (Ramanathan, 2003). Az ilyen típusú magyarázóváltozók modellben történő szerepeltetésének oka a modell magyarázóerejének növelése, nélkülük az értéke kisebb lenne. A végső modell regressziós együtthatóinak értelmezése során a 18 magyarázó változóból 5 magyarázóváltozóhoz tartozó regressziós együttható esetében ellenkezô előjelú eredmény született, mint az a közgazdasági elméletek alapján előzetesen feltételezhető volt.

Ennek oka az említett magyarázóváltozók és a modellben szereplő más magyarázóváltozók közötti szoros kapcsolat, amit a többváltozós matematikai statisztikai irodalom multikollinearitás címszó alatt tárgyal. A multikollinearitás annak ellenére, hogy a modellben szereplő magyarázóváltozókhoz tartozó regressziós együtthatók, és elôjeleik értelmezésében gondot okoz, nem ront a modell előrejelzô képességén, hanem javíthatja azt, így egyszerúen figyelmen kívül hagyható komolyabb következmények nélkül. A multikollinearitás tényét igazolni a regressziós modellben szereplő magyarázóváltozók közötti magas korrelációs együtthatók értékeivel lehet.

\section{Javaslatok határon átíveló akvizíciós vagy fúziós tranzakciót tervezô magyar vállalatoknak}

Határon átívelő M\&A tranzakció előtt álló magyar vállalatoknak egy sikeres tranzakció végrehajtásának elósegítése céljából javasolt a figyelem szentelése a tranzakció megtervezésénél és a célvállalat kiválasztásánál mind a hagyományos megközelítési mód által preferált kemény (könnyen számszerúsíthető és gyakran pénzben is kifejezhetô) változókra, mind a szervezeti megközelítési mód által preferált puha (nehezen számszerúsíthetố és gyakran alig értelmezhetô) változókra.

Jelentôs lehet a szerepe a felvásárló és célvállalat országai közti különbségeknek a tranzakció utáni teljesítményre. A felvásárló és cél vállalat országai közti - kulturális különbség, - információs és telekommunikációs kiadások különbsége, - központi politikai és gazdasági irányítás közti minôségi különbség mind ellentétes irányú (negatív), azaz teljesítménycsökkentő hatású kapcsolat meglétét sejteti. Ezzel szemben a célvállalat országában élő, a felvásárló vállalat országbéli kisebbség aránya azonos irányú (pozitív), azaz teljesítménynövelố hatású kapcsolat meglétét vetíti előre.

Javasolt a minél szorosabb iparági kapcsolat a felvásárló és a célvállalat között. Minél nagyobb a cél- és a felvásárló vállalat ország kockázatai közti különbség, annál nagyobb az elvárható hozam. Célszerú a létrejött közös vállalat tranzakció utáni átlagos likviditási gyorsráta, valamint átlagos készletek forgási sebességi mutatóinak értéknövelése. Nincs negatív hatása a létrejött közös vállalat tranzakció utáni átlagos idegentóke-aránya növelésének sem, amennyiben ez az átlagos rövid távú eladósodottság növelésében nyilvánul meg. A felsorolt mutatók mind kifejezetten pozitív, azaz teljesítménynövelő hatású kapcsolat meglétét sejtetik.

Ajánlott azonban a létrejött közös vállalat számára a tranzakció utáni átlagos hosszú távú eladósodottság, valamint az átlagos vevoók aránya a forgóeszközökön belül mutatók értékeinek minél alacsonyabb szinten tartása, mivel ezek a mutatók ellentétes irányú (negatív), azaz teljesítménycsökkentô hatású kapcsolat meglétét sejtetik.

A kialakított kombinált diszkriminancia és kombinált végső regressziós modellek lehetőséget nyújtanak a tranzakciót tervezó felvásárló vállalatoknak, hogy a modellek korlátain belül előrejelzéseket készítsenek egy feltételezett célvállalattal történố tranzakció várható kimenetelére. A kombinált diszkriminancia modell a tervezett tranzakció teljes siker, részleges siker, részleges kudarc vagy teljes kudarc várható eredmények közti besorolásra tesz előrejelzést, míg a kombinált 
végsố regressziós modell a feltételezett tranzakció utáni várható referenciahozammal csökkentett BAHR-hozam értékére ad előrejelzést, természetesen a felvásárló vállalat szempontjából.

\section{A kutatás lehetséges kiterjesztése}

A kutatás során a legnagyobb problémát a megfelelő minta megszerzése, valamint az elemzések elvégzéséhez szükséges releváns adatokhoz való hozzájutás jelentette. Ez a probléma elméletileg könnyen kiküszöbölhetố lenne, mivel léteznek olyan adatbázisok, amelyek napi frissítéssel tartalmazzák az összes eddigi megkötött M\&A tranzakciót és tranzakciónként több mint 60 adatot a részt vevő felekról, illetve a tranzakcióról magáról. Ezek azonban kereskedelmi adatbázisok, szigorúan profitorientáltan múködnek, és díjaik a kutatók számára szinte megfizethetetlenek. Ilyen adatbázison történő felépítése a kidolgozott modellnek valószínúleg sokkal pontosabb eredményekhez vezetne. Ezen eredmények érvényessége, valamint a belőlük levont következtetések így jobban általánosíthatók lennének.

A kombinált végsố regressziómodellhez tartozó eredményváltozó alakulásának 22,6\%-ban meg nem magyarázott részének feltárása további vizsgálatok és elemzések elvégzését kívánja meg. Adatok hiányában nem volt mód olyan magyarázóváltozók modellbe történô bevonására, mint például a fizetés módja, elôzetes tapasztalatok vagy a kifizetett prémium nagysága, amelyek viszont a szakirodalom alapján a M\&A tranzakciók sikerességét befolyásoló tényezók közé sorolhatók. Ezen tényezók, valamint újabb, eddig nem alkalmazott magyarázóváltozók elemzésbe történő bevonásával feltételezhetôen javítható lenne a modell illeszkedése, amennyiben ezen új változók valóban szoros kapcsolatban állnak az eredményváltozóval.

A minta összetételének módosításával akár longitudinálissá is tehető a vizsgálat, ami az idóbeli változások kimutatását is lehetővé teszi. A minta méretének növelésével pedig javítható lenne a becslések pontossága is.
A mintavételi hiba azonban ennek ellenére sem küszöbölhetô ki, mivel egy része eleve elkerülhetetlen, és a módszer szükségszerú velejárója. Továbbá a kialakított modellben egymásra épülő többváltozós matematikai és statisztikai módszerekról van szó, amelyek mindegyike esetében a statisztikai hibatag a módszertanok sajátosságából fakad, így ezek az elemzés során halmozódnak, értékük pedig rohamosan nó, rontva ezzel a becslések pontosságát. Ezen együttes hiba nem megszüntethetô, hanem csak minimalizálható.

Mindazonáltal szükséges a témához kapcsolódó kutatások folytatása, hogy pontosíthassuk a már feltérképezett tényezốk hatásait a határon átívelő akvizíciók és fúziók sikerességére és újabb, eddig még nem vizsgált változók hatásaira fényt deríthessünk, hatékonyabban segítve ezzel a tranzakcióban érintett vállalatok döntéshozóit.

\section{Felhasznált irodalom}

Black, E. L. - Carnes, T. A. - Jandik T. (2001): The long term success of cross-border mergers and acquisitions. Social Science Research Network Electronic Paper Collection: http://papers.ssrn.com/paper.taf?abstract_id=270288

Conn, Ch. - Cosh, A. - Guest, P. - Hughes, A. (2001): Long-run share performance of U.K. firms engaging in cross-border acquisitions. ESCR Centre for Business Research, University of Cambridge, Working Paper No. 214

Hitt et al. (1998): Current and Future Research Methods in Strategic Management. Organisational Research Methods, Vol. 1 No. 1, pp. 6-44. pp.

King, D. R. (2002): The State of Post Acquisition Performance Literature: Where to from Here? Indiana University at Bloomington School of Business Academy of Management Interactive Paper

Kleinert, J. - Klodt, H. (2002): Causes and Consequences of Merger Waves. Kiel Working Paper No. 1092. Kiel Institute of World Economics Kiel.

Ramanathan R. (2003): Bevezetés az ökonometriába alkalmazásokkal. Panem. Budapest.

\section{E SZÁMUNK SZERZÖI}

Dr. Bokor Attila, egyetemi docens, Budapesti Corvinus Egyetem; Dr. Demeter Krisztina, egyetemi docens, Budapesti Corvinus Egyetem; Dr. Görög Mihály, egyetemi docens, Budapesti Corvinus Egyetem; Mikulás Gábor, tanácsadó, GM Consulting; Köntös Nelli, egyetemi hallgató, ELTE BTK; Balogh Csaba, PhD. hallgató, Budapesti Corvinus Egyetem

\section{VEZETÉSTUDOMÁNY}

